\title{
OBITUARY
}

\section{Ludwig Teleky}

Industrial medicine has lost a leading international figure and a beloved fellow-worker through the death of Dr. Ludwig Teleky. He was born in Vienna, the son of Hermann Teleky, M.D. He died in the Jewish Memorial Hospital, New York, on August 20, 1957, aged 85 years.

He was lecturer in social medicine in the University of Vienna from 1909 to 1919 . From 1919 to 1932 he was Director of the Postgraduate Academy of Public Health and Industrial Medicine at Dusseldorf, and at the same time Medical Inspector of Factories for the Rhineland, and a member of the Central Council for Health in Berlin. In 1932 in the Nazi persecution of the Jews he was deprived of these appointments and returned to Vienna.

He was a founder member of the Permanent International Commission on Industrial Medicine in 1906, and in 1951 was elected an honorary life member of the Commission in recognition of his eminence.

Teleky attended the 8th International Congress on Industrial Medicine at Frankfurt in 1938. This Congress was interrupted by the Munich crisis and the delegates dispersed. It was necessary for Teleky's safety for his friends to get him over the border into Switzerland. Friends in Austria and America then arranged for him to go to the United States of America, where he was appointed to a lectureship in the University of Chicago, which he held from 1939 to 1944.

In 1944 Dr. Leonard Greenburg, now Commissioner of the Air Pollution Control Department of New York, invited Teleky to work with him in the Labour Division of the New York State Department of Industrial Hygiene.

While in New York Teleky devoted much of his time to writing and from his pen flowed many articles and a number of books upon occupational health. He edited the Encyclopaedia of Industrial Diseases published by the International Labour. Office. His book " The History of Factories and their Hygiene" was published by the Columbia Press in 1948, and "Gewerbliche Vergiftungen" was published by Springer-Verlag, Berlin, in 1955.

The Grand Cross of Merit was conferred on Dr. Teleky by President Heuss of the German Federal Republic, and in 1952 in a new part of Hamm, one of the ancient Hanse towns of Germany, a street was called by his name.

His wife died in 1953 . He is survived by two daughters, Anna, a worker in social medicine now living in Vienna, and Agnes, a Doctor of Philosophy of the University of Frankfurt, who is engaged in social science work in London.

T. E. A. Stowell
Professor E. L. Collis, C.B.E., D.M., M.R.C.P.

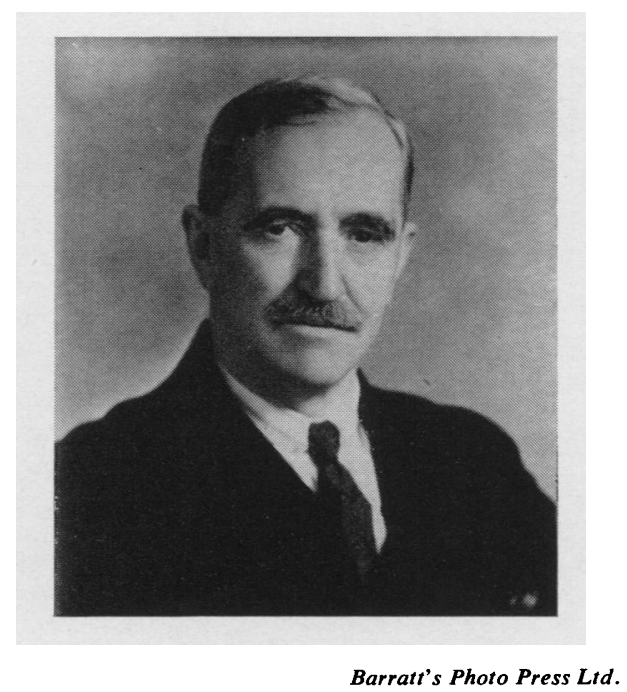

Professor E. L. Collis, Emeritus Professor of Preventive Medicine in the University of Wales, died in hospital at Forres, Morayshire, on October 1, 1957, aged 86 years. By his death Great Britain has lost one of its pioneers of industrial medicine.

Edgar. Leigh Collis was born at Stourbridge on November 25, 1870, the son of W. B. Collis, J.P. From Stourbridge Grammar School he went on to Charterhouse, and then to Keble College, Oxford. A notable sportsman in those days, he was president of the Oxford University Swimming Club and represented the university in athletics against Cambridge in 1892 and 1893, tying for first place in the hurdles in the latter year. After gaining first class honours in the Natural Science School at Oxford he went to St. Thomas's Hospital for his clinical studies, qualifying in 1896 and graduating B.M., B.Ch. in the following year. He proceeded to the D.M. in 1919, and became M.R.C.P. in 1920. For the first 10 years or so of his professional life he was a general practitioner in Stourbridge, where he was certifying factory surgeon and on the staff of the Corbett Hospital.

In 1908 he joined the staff of the Factory Department of the Home Office as a medical inspector of factories, and soon became a leading authority on pneumoconiosis, the subject of his Milroy Lectures in 1915. He had also made various investigations on behalf of Home Office departmental committees, including the study of heat stress in hot industries.

When, early in the first World War, the Minister of 